\title{
In vitro biological assessment of berberis vulgaris and its active constituent, berberine: antioxidants, anti-acetylcholinesterase, anti-diabetic and anticancer effects
}

Abeer E Abd El-Wahab², Doaa A Ghareeb ${ }^{1,2^{*}}$, Eman EM Sarhan ${ }^{3}$, Marwa M Abu-Serie $^{2}$ and Maha A El Demellawy ${ }^{2}$

\begin{abstract}
Background: Berberis vulgaris is a well known plant with traditional herbal medical history. The aims of this study was to bioscreen and compare the in vitro biological activity (antioxidant, cholinergic, antidaibetic and the anticancer) of barberry crude extract and berberine active compound.

Methods: The effect of $B$. vulgaris extract and berberine chloride on cellular thiobarbituric acid reactive species (TBARS) formation, diphenyle-a-picrylhydrazyl (DPPH) oxidation, cellular nitric oxide (NO) radical scavenging capability, superoxide dismutase (SOD), glutathione peroxidase (GPx), acetylcholinesterase (AChE) and a-gulcosidase activities were spectrophotometrically determined. On the other hand, the effect of extract and berberine as anticancer was estimated on three different cell lines which were MCF-7, HepG-2, and Caco-2 cells by using neutral red uptake assay which compared with control normal cells (PBMC).

Results: Our results showed that barberry crude extract contains $0.6 \mathrm{mg}$ berberine/mg crude extract. Barberry extract showed potent antioxidative capacity through decreasing TBARS, NO and the oxidation of DPPH that associated with GPx and SOD hyperactivation. Inhibitory effect of berberis crude extract on a-glucosidase was more potent than that of berberine chloride, while both had the same AChE inhibitory effect. Besides, different concentrations of both berberine chloride and barberry ethanolic extract showed to have no growth inhibitory effect on normal blood cells (PBMC). Otherwise, both berberine chloride and barberry ethanolic extract showed to have inhibitory effect on the growth of breast, liver and colon cancer cell lines (MCF7, HepG2 and CACO-2, respectively) at different incubation times starting from $24 \mathrm{hrs}$ up to $72 \mathrm{hrs}$ and the inhibitory effect increased with time in a dose dependant manner.

Conclusion: This work demonstrates the potential of the barberry crude extract and its active alkaloid, berberine, on suppressing lipid peroxidation, suggesting a promising use in the treatment of hepatic oxidative stress, Alzheimer and idiopathic male factor infertility. Beside, berberis vulgaris ethanolic extract is safe non-toxic extract as it was not inhibit the growth of PBMC that can induce cancer cell death that could return to its powerful antioxidant activity.
\end{abstract}

Keywords: Bioscreening, DPPH, Acetylcholinesterase, a-glucosidase, Breast cancer, Hepatoma, CACO-2, PBMC

* Correspondence: d.ghareeb@yahoo.com

${ }^{1}$ Biochemistry Department, Faculty of Science, Alexandria University, P.O. Box:

21511, Alexandria, Egypt

${ }^{2}$ Medical Biotechnology Department, Genetic Engineering \& Biotechnology

Research Institute, City for Scientific Research \& Technology Applications,

Alexandria, Egypt

Full list of author information is available at the end of the article 


\section{Background}

As it is increasingly believed now that traditional medicines become more popular worldwide, there is accumulating evidence suggesting medicinal plants are unlimited reservoirs of drugs. The amazing structural diversity among their active components makes them a useful source of novel therapeutics. Researchers with interest in natural products have intensified their efforts towards scientific evaluation of traditional medicines. The World Health Organization (WHO) estimates that herbal medicine is still the most common source for primary health care of about $75-80 \%$ of the world's population, mainly in the developing countries, because of better cultural acceptability, better compatibility with the human body and fewer side effects [1].

Berberis vulgaris is a shrub in the family Berberidaceae, native to central and southern Europe, northwest Africa and western Asia. It grows in a variety of soils, though is primarily cultivated in cooler regions [2-4]. Its fruit is an oblong red berry $7-10 \mathrm{~mm}$ long and $3-5 \mathrm{~mm}$ broad, ripening in late summer or autumn; it is edible but very sour, and rich in vitamin C. Barberry is extensively used as food additive and its juice is recommended to cure cholecytitis [5].

Barberry has a long history of use in traditional eastern and western herbalism [6].

Berberis vulgaris as well as other berberine (BER) containing plants [7] are used medicinally in virtually all-traditional medical systems, and have a history of usage in Ayurvedic, Iranian and Chinese medicine dating back at least 3,000 years [8]. Ancient Egyptians used barberry fruit with fennel seeds to ward off pestilent fevers [6]. Indian ayurvedic physicians used barberry in the treatment of dysentery and traditional Iranian medicine uses its fruit as a sedative [6,9]. In northern Europe barberry was used to treat gall bladder and liver problems, while it was used in the treatment of abnormal uterine bleeds and rheumatism in Russia and Bulgaria $[10,11]$. In North America, the Eclectics used barberry for treatment of malaria and as a general tonic [12]. Also, the American Indians found it effective in improving appetite and used its dried fruit as a gargle $[13,14]$.

Phytochemical analysis of root, stem or bark extract of $B$. vulgaris demonstrated the presence of protoberberines and bisbenzyl-isoquinoline alkaloids (berbamine, tetrandrine and chondocurine, (Table 1) for which anti-inflammatory and immuno-suppressive activities have also been well established [15]. Medicinal properties for all parts of the plant have been reported, including tonic, antimicrobial, antiemetic, antipyretic, antipruritic, antioxidant, anti-inflammatory, hypotensive, antiarrhythmic, sedative, antinociceptive, anticholinergic and cholagogue actions, and it has been used in some cases like cholecystitis, cholelithiasis, jaundice, dysentery, leishmaniasis, malaria and gall stones [16] (Table 2). Furthermore, BER, an isoquinoline
Table 1 Compounds isolated from berberis vulgaris

\begin{tabular}{llcc}
\hline Compound & Nature & Compound & Nature \\
\hline Aromoline & Alkaloid & Oxyberberine & Alkaloid \\
Berbamine & Alkaloid & Oxycanthine & Alkaloid \\
Berberine & Alkaloid & Palmatine & Alkaloid \\
Berlambine & Alkaloid & Quercentin & Flavonoid \\
Bervulcinc & Alkaloid & Rutin & Flavonoid \\
Columbamine & Alkaloid & (-)-tejedine & Alkaloid \\
Hydroxycanthine & Alkaloid & Yatronizine & Alkaloid \\
Isocorydine & Alkaloid & & \\
\hline
\end{tabular}

alkaloid and the major ingredient of this plant, has been used for treating diarrhea and gasterointestinal disorders for a long time $[17,18]$. It has multiple pharmacological effects including; antimicrobial activity against 54 microorganisms [19-21], inhibition of intestinal ion secretion and smooth muscle contraction, inhibition of ventricular tachyarrhythmia, reduction of inflammation, stimulation of bile secretion and bilirubin discharge [22]. In spite of extensive applications and numerous properties, the mechanism of action in most of its effects is not exactly clear. Some of these properties may occur due to antihistaminic and anticholinergic effects.

Among berberine multiple pharmacological actions, anti-inflammatory activity has been extensively studied [23]. Antipyretic activity of berberine sulfate has also been shown by Sabir and Bhide 1971 using a model of experimentally induced fever in rats [22]. This effect has been found to be approximately three times greater than sodium salicylate. Anti-colitic property is another pharmacological effect has been demonstrated for berberine by Zhou and Mineshita [24].

The barberry phenolic compounds include anthocyanins and carotenoid pigments [22-26]. Several pharmacological effects such as antioxidant and cytoprotective [27], inhibitory effects on capillary permeability [28] and epidermal growth factor [29] anticholinergic and antihistaminergic [27], have been demonstrated for anthocyanins and berberry fruit extract (BFE).

The aim of this study was to compare the in vitro biological activity (antioxidant, cholinergic, antidaibetic and the anticancer) of barberry crude extract and berberine active compound.

\section{Methods}

\section{Human and animal biological samples}

Human participants and their biological materials (blood) met the ethical standards for donor approval required by national regulatory bodies. Blood samples were collected from ten healthy subjects after they signed consent 
Table 2 The pharmacological effects of Berberis vulgaris (NAPALERT; natural products alert database)

\begin{tabular}{|c|c|c|c|}
\hline System & Effect & Part of plant & Preparation \\
\hline \multirow[t]{2}{*}{ Cardiovascular } & Hypotensive activity & Dried root & Alkaloid fraction \\
\hline & & Dried fruit & Aqueous extract \\
\hline Gastrointestinal & Gastric secretory stimulation & Root & Ethanol- $\mathrm{H}_{2} \mathrm{O}(67 \%)$ extract \\
\hline \multirow[t]{6}{*}{ Endocrine } & Choleretic activity in rat & Dried root & Total alkaloids \\
\hline & Choleretic activity & Stem bark & \\
\hline & $\begin{array}{l}\text { Increases tone of the digestive tract and gives rise to increased } \\
\text { and irregular peristalsis }\end{array}$ & Dried root & \\
\hline & Anticholinergic activity in guinea pig ileum & Dried fruit & Decoction \\
\hline & Menstruation induction effect in guinea pig & Stem & Ethanol (95\%) extract \\
\hline & Uterine stimulant effect in cat, rabbit and guinea-pig & Leaf & Ethanol-acetone (50\%) extract \\
\hline \multirow[t]{2}{*}{ Immune system } & Antibody formation suppression in mouse & Dried root & Alkaloid fraction \\
\hline & Antiinflammatory activity & Root & Alkaloid fraction \\
\hline \multirow[t]{2}{*}{ Organisms } & Complement alternative pathway inhibition & Root & Ethanol (I00\%) extract \\
\hline & Delayed type cutaneous hypersensitivity inhibition & & $\begin{array}{l}\text { Alkaloid fraction and ethanol (95\%) } \\
\text { extract Alkaloid fraction }\end{array}$ \\
\hline \multirow{4}{*}{$\begin{array}{l}\text { Central nervous } \\
\text { system }\end{array}$} & Antipyretic activity in rat & Dried bark & Alkaloid fraction \\
\hline & & Dried fruit & Ethanol (95\%) extract \\
\hline & Narcotic antagonist activity & Dried root & \\
\hline & Sedative & Fruit & \\
\hline Renal & Diuretic activity in rat & Dried bark & Alkaloid fraction \\
\hline \multirow[t]{2}{*}{ Other } & Toxicity assessment in mouse $-\mathrm{LD}_{50}=5200 \mathrm{mg} / \mathrm{kg}$ & Dried root & Alkaloid fraction \\
\hline & Toxicity assessment in mouse $-\mathrm{LD}_{50}=2.6 \pm 022 \mathrm{~g} / \mathrm{kg} \mathrm{b} \mathrm{w}$ & & \\
\hline \multirow{2}{*}{$\begin{array}{l}\text { Male } \\
\text { reproduction }\end{array}$} & Idiopathic ma factors due to oxidative damage & Root & Crude methanolic (95\%) extraction \\
\hline & & & Crude acetic acid (5\%) extraction \\
\hline
\end{tabular}

informed the use of their blood in this study Consents' approval and all study protocols for animal and biological tissue samples treatment, involved in this study, were firmly subjected to ethical instructions outlined by Animal Ethics Committees (AEC) that published via The National Health and Medical Research Council (NHMRC) policies and guidelines that recommended by the Egyptian Ministry of Health and Population, High Committee Of Medical Specialties, Arab Republic of Egypt [30]. This study was permission granted from the Biomedical technology, SRAT-city and Biochemistry Department, Faculty of Science, Alexandria University, following approval of the Research Ethics Committee, Faculty of Pharmacy, Alexandria University.

\section{Barberry, Berberis vulgaris}

Barberry's roots were purchased and authenticated by Prof. Salma El-dareir, Botany Department, Faculty of Science, Alexandria University, Egypt. Firstly, this classification was being dependent on the data about the plant published in Dargon Herbarium [31]. After classification, the plant roots were separated then dried at room temperature, powdered, sieved, and stored prior to further use. Dried barberry roots were phytochemically screened for alkaloids, phobatannins, saponnins, flavonoids, steroids, terpenoids and cardiac glycosides [1].

\section{Barberry crude extract preparation}

The dried powdery roots of barberry were exhaustively defatted with petroleum ether then dried in fresh air to evaporate the solvent. The dried roots were used to prepare the ethanolic crude extract by subjecting to steam distillation method using Soxhlet apparatus in which the powder was added in glass thimble and boiled ethanol extracted the active compounds for 8 hours. The ethanolic extract was concentrated to minimum volume using rotary evaporator at $60^{\circ} \mathrm{C}$ and $100 \mathrm{rpm}$ (Büchi, Switzerland) then lyophilized (DISHI, DS-FD-SH10, Xi'an Heb Biotechnology Co, China) to obtain a powder extract of barberry (25\%). The barberry extract powder form was kept at $-20^{\circ}$ $\mathrm{C}$ until subjected to further biochemical analysis. 


\section{HPLC analysis}

The ethanolic extract was analyzed using HPLC (Series 500 Bio-Tek Instrument, Milano, Italy) to determine the berberine concentration in the extract. The analytes were separated by a Zorbax Eclipse XDB-C18 $(250 \times 4.6 \mathrm{~mm}$ i.d., $5 \mu \mathrm{m}$ particle size) column (Agilent, Santa Clara, CA, USA).

The freeze-dried Berberis vulgaris extracts were dissolved in equal volume water: ethanol solution $(1 \mathrm{mg} /$ $\mathrm{ml}$ ) and were filtered through a $0.22-\mu \mathrm{m}$ syringe filter prior to HPLC analysis. The operating temperature was maintained at $30^{\circ} \mathrm{C}$ and the detector was operated at a wavelength of $254 \mathrm{~nm}$. The mobile phase was a mixture of two solvent compositions, solvent A (deionized water) and solvent $\mathrm{B}$ (methanol). The program was started with $40 \%$ solvent $\mathrm{A}$ and $60 \%$ solvent B at a solvent flow of $0.8 \mathrm{ml} / \mathrm{min}$ and injection volume of $20 \mu \mathrm{l}$ [32].

\section{Preparation of berberine chloride}

Berberine chloride was commercially available from Sigma-Aldrich where, different concentrations of berberine chloride were prepared by dissolved certain weights at $1 \mathrm{ml}$ of $10 \%$ ethanol.

\section{Preparation of liver homogenate}

Six Balb/c mice were obtained from animal of house of medical research institute, Alexandria University. After anesthesia, liver was isolated and washed in cold saline, and then one gram of each liver was homogenized in $9 \mathrm{~mL}$ phosphate buffer saline. The homogenate was centrifuged at 3000 and metabolites containing supernatant was decanted for further biochemical estimations.

\section{Biochemical assays}

1. Determination of Acetylcholinesterase (AChE) activity AChE activity was measured according to the method of Ellman et al. [33]. $130 \mu \mathrm{L}$ phosphate buffer (0.1 M pH 7.4) were added to a mixture of $20 \mu \mathrm{L}$ of liver homogenate and $20 \mu \mathrm{L}$ of barberry extract (test) or organic solvent (control), then incubated for $45 \mathrm{~min}$ at $37^{\circ} \mathrm{C} .5 \mu \mathrm{L}$ of substrate ACTI $(75 \mathrm{mM})$ were added, mixed well and incubated for $15 \mathrm{~min}$ at $37^{\circ} \mathrm{C}$. $60 \mu \mathrm{L}$ DTNB $(0.32 \mathrm{mM})$ were added and left for $5 \mathrm{~min}$. The absorbance was measured at $405 \mathrm{~nm}$ and the specific activity was calculated.

2. Determination of $\alpha$-glucosidase activity Method mentioned by Han and Srinivasan [34] was carried out with a slight modification to estimate the effect of barberry extract on $\alpha$-glucosidase (EC 3.2.1.20) activity. $100 \mu \mathrm{L}$ of barberry extract (test), organic solvents (control) or $\mathrm{dH} 2 \mathrm{O}$ (blank) were diluted with $2.5 \mathrm{~mL}$ of $0.1 \mathrm{M}$ phosphate buffer,
$\mathrm{pH}$ 7.4. $100 \mu \mathrm{L}$ of liver homogenate were added, mixed well and incubated in a water bath with the reaction mixture at $30^{\circ} \mathrm{C}$ for $5 \mathrm{~min} .500 \mu \mathrm{L}$ PNPG, $5 \mathrm{mM}$, were added and the reaction was allowed to proceed for $15 \mathrm{~min}$. The reaction was stopped by the addition of $2 \mathrm{~mL}$ of $1 \mathrm{M} \mathrm{Na}_{2} \mathrm{CO}_{3}$. The producing color was spectrophotometrically detected at $400 \mathrm{~nm}$. A unit of enzyme activity was defined as nmoles of p-nitrophenol released/min.

3. Determination of Thiobarbaturic acid reactive substance (TBARS) level in induced lipid peroxidation model Two $\mathrm{mL}$ of barberry extract or berberine chloride (test), the organic solvent (control) or distilled water $\left(\mathrm{dH}_{2} \mathrm{O}\right)$ (blank) were incubated with equal volume of liver homogenate for about $45 \mathrm{~min}$ at $37^{\circ} \mathrm{C}$. In vitro tissue lipid peroxidation was induced by adding $\mathrm{H}_{2} \mathrm{O}_{2}$ and ferrous sulphate $\left(\mathrm{FeSO}_{4} \cdot 7 \mathrm{H}_{2} \mathrm{O}\right)$ at a final concentration of $1 \mathrm{mM}$ and $0.5 \mathrm{mM}$, respectively, in both test and control reaction mixtures. After an incubation period of about $30 \mathrm{~min}$ at $37^{\circ} \mathrm{C}$, butylated hydroxyl toluene (BHT) was added at a final concentration of $0.02 \%$ and mixed carefully to stop the peroxidation reaction. The mixtures were centrifuged at $3000 \mathrm{rpm}$ for $15 \mathrm{~min}$, and then $1 \mathrm{~mL}$ of the resultant supernatant was mixed with $1 \mathrm{~mL}$ of $15 \%$ trichloroacetic acid (TCA) followed by centrifugation at $3000 \mathrm{rpm}$ for $10 \mathrm{~min}$ [1].

Then TBARS was determined in previous solution according to the method described by Wills [35]. $1 \mathrm{~mL}$ of protein free supernatant was mixed with $500 \mu \mathrm{L}$ of $0.7 \%$ thiobarbituric acid (TBA), heated in boiling water bath for $45 \mathrm{~min}$, cooled and the colour in the supernatant was detected at $532 \mathrm{~nm}$. The TBARS level was calculated against a control according to the following equation: TBARS level $(\mathrm{nmol} / \mathrm{ml})=$ At $/ 0.156$

4. Determination of Diphenyle - $\alpha$-picrylhydrazyl (DPPH) radical scavenging

$\%$ scavenging $=[($ A control $-A$ sample $] / A$ control $\times 100$

DPPH radical scavenging assay of the total extract was performed by using the previously established and modified methodology by Choi et al. [36]. Assays were performed in flat bottom polystyrene 96 well microtiter plates. To $100 \mu \mathrm{L}$ of each sample (1-6 mg/ $\mathrm{ml})$ in $\mathrm{EtOH} 25 \mu \mathrm{L} \mathrm{DPPH}(1 \mathrm{mM})$ in ethanol was added. The resultant mixture was briefly shaken and maintained at room temperature, in the dark for $30 \mathrm{~min}$. At the end of this period, the absorbance (A) of the mixture was measured at $490 \mathrm{~nm}$, using ELISA. Scavenging ratio of DPPH assay calculated as follows: 
5. Determination of nitric oxide scavenging activity

NO scavenged $=[(A$ control $-A$ test $) / A$ control $] \times 100$

Nitric oxide was determined by the method described by Green et al. [37], where nitric oxide was generated from sodium nitroprusside and measured by Griess reaction. Scavenger of nitric oxide competes with oxygen leading to reduced production of nitric oxide. Sodium nitroprusside (5 mM) in phosphate buffered saline ( $\mathrm{pH} 7.2)$, was mixed with different concentrations $(1-6 \mathrm{mg} / \mathrm{mL}$ ) of the extract and incubated at $25^{\circ} \mathrm{C}$. Samples from the above were reacted with Griess reagent (1\% sulphanilamide, $2 \%$ phosphoric acids and $0.1 \%$ Naphthylethylendiamine hydrochloride). The absorbance of the chromophore (A) formed during the diazotization of nitrite with sulphanilamide and subsequent coupling with naphthylethylenediamine was read at $546 \mathrm{~nm}$. The scavenged ratio of $\mathrm{NO}$ calculated as follows:

6. Determination of SOD activity

Twenty microliters of liver homogenate supernatant (test) or buffer (reference) and $20 \mu \mathrm{l}$ of extract or berberine chloride different concentrations were added to $1 \mathrm{~mL}$ buffer solution and incubated at $37^{\circ} \mathrm{C}$ for $45 \mathrm{~min} .10 \mu \mathrm{l}$ pyrogallol $(20 \mathrm{mM}$ in $\mathrm{HCl}$, $10 \mathrm{mM}$ ) was added to the previous solution and the absorbance of test (At) or reference (Ar) was measured at $420 \mathrm{~nm}$ against air after 30 and $90 \mathrm{~s}$. The percentage inhibition of pyrogallol autoxidation by supernatant was calculated according to the following equation:

$$
\begin{aligned}
& \text { The percentage inhibition } \\
& =100-[(\text { At } / \mathrm{min} / \mathrm{ml} \text { sample }) / \\
& \quad(\text { Ar } / \mathrm{min} / \mathrm{ml} \text { reference }) \times 100]
\end{aligned}
$$

The specific activity of serum SOD as ng/min/mg protein was calculated with dividing the value of $\mathrm{SOD}$ in $\mathrm{ng} / \mathrm{min} / \mathrm{ml}$ by protein concentration in the sample.

One unit of SOD activity is defined as the amount of enzyme which inhibits the rate of auto-oxidation of pyrogallol by $50 \%$. From the standard curve it was found that, one unit equals $153 \mathrm{ng}$. The sample enzyme activity in $\mathrm{U} / \mathrm{mg}$ protein was obtained by diving value in $\mathrm{ng} / \mathrm{min} / \mathrm{mg}$ protein by 153 [38].

7. Determination of liver glutathione peroxidase (GPx) activity

Fifty microliters of liver homogenate were incubated with equal volume of different extract or berberine chloride different concentrations for $45 \mathrm{~min}$ at $37^{\circ} \mathrm{C}$, then were added to $100 \mu \mathrm{l} \mathrm{GSH}$, $100 \mu \mathrm{l}$ cummen $\mathrm{H}_{2} \mathrm{O}_{2}$ and $750 \mu \mathrm{l}$ Tris- $\mathrm{HCl}$,
$\mathrm{pH} 7.6$ (test) and incubated at $37^{\circ} \mathrm{C}$ for $10 \mathrm{~min}$. For control, $50 \mu \mathrm{l}$ diluted supernatant and100 $\mu \mathrm{l}$ GSH were added to $750 \mu \mathrm{l}$ Tris-HCl, $\mathrm{pH} 7.6$, then incubated at $37^{\circ} \mathrm{C}$ for $10 \mathrm{~min}$. One milliliter TCA was added to test and control as well as $100 \mu \mathrm{l}$ cummen $\mathrm{H}_{2} \mathrm{O}_{2}$ were added to control then both were centrifuged at 3000 r.p.m. for $20 \mathrm{~min}$ and then the supernatants were separated off. One milliliter of supernatants was added to $2 \mathrm{ml}$ Tris- $\mathrm{HCl}, \mathrm{pH} 8.9$ and $100 \mu \mathrm{l}$ DTNB then incubated for 5 min [39]. The absorbances of test and control (Ac) were read at $412 \mathrm{~nm}$ against distilled water. The activity of liver GPx was calculated with the following equation;

$$
\begin{aligned}
& \text { GPx activity }(U / g \text { wet tissue }) \\
& \quad=E \times 6.2 \times 10 \times 10 / 13.1 \times 0.05 \times 10
\end{aligned}
$$

\section{In Vitro anticancer assay}

In order to determine the safe concentrations of both barberry ethanolic extract and berberine standard that can be used for In Vitro cell culture; normal peripheral blood mononuclear cells (PBMC) were isolated from a healthy individual by Ficoll-Hypaque (density $1.077 \mathrm{~g} / \mathrm{L}$, Lonza, USA) gradient centrifugation. PBMC were collected and washed using HBSS, then cell viability and count were determined using Trypan blue exclusion test. After collecting the PBMC, cells were suspended at concentration of $1 \times 10^{6}$ cell $/ \mathrm{ml}$ in RPMI 1640 (Lonza) $25 \mathrm{mM} \mathrm{N-2-}$ hydroxyethylpiperazine- $N$ '-2-ethanesulfonic acid (HEPES) (Lonza), $4 \mathrm{mM} \mathrm{L}$-glutamine (Lonza), 100U of penicillin and $100 \mu \mathrm{g}$ streptomycin (Lonza) and 10\% FBS (Lonza). In 96 well plate, $1 \times 10^{5}$ cell/well were seeded with different concentrations ranging from 0 to $100 \mu \mathrm{g} / \mathrm{ml}(20,40,60$, $80,100 \mu \mathrm{g} / \mathrm{ml}$ ) of barberry ethanolic extract, or berberine standard for $72 \mathrm{hr}$ at $37^{\circ} \mathrm{C}$ incubator with $95 \%$ humidity and $5 \% \mathrm{CO}_{2}$.

The cytotoxic effect of the different concentrations of the extract and the standard were determined using the neutral red uptake assay [40]. Briefly, Neutral red working solution $(80 \mu \mathrm{g} / \mathrm{ml})$ (Serva, Austria) was incubated overnight at $37^{\circ} \mathrm{C}$. In each well of the incubated cells, culture media was removed and $100 \mu \mathrm{l}$ of neutral red medium were added then incubated for $3 \mathrm{hr}$ to allow for vital dye incorporation into living cells. The neutral red media was removed and rapid rinsed with $150 \mu$ l HBSS. Dye was extracted from the cells by adding $150 \mu \mathrm{l}$ extraction buffer (1\% acetic acid: $50 \%$ ethanol (96\%): $49 \%$ deionized $\mathrm{H}_{2} \mathrm{O}$ ) followed by rapid agitation for at least $10 \mathrm{~min}$ on micrometer plate shaker. The extract neutral red color intensity was measured at $490 \mathrm{~nm}$ in a microtiter plate reader spectrophotometer. 
Using the relation between used concentrations and neutral red intensity value, $\mathrm{IC}_{50}$ of the barberry ethanolic extract and standard berberine chloride was calculated.

Following the same method selected concentrations of both barberry ethanolic extract and standard berberine chloride were used to examine their effect on different cancer cell lines. In a 96-well tissue culture plates, MCF7, HepG-2, Caco-2 and EL4 cells were plated each in its respective culture media, at a density of 3000 cells/well, 11000 cells/well, 6000 cell/well and 15000 cells/well, respectively. Cells were left to adhere by incubation for $24 \mathrm{hr}$ at $37^{\circ} \mathrm{C}, 95 \%$ humidity and $5 \% \mathrm{CO}_{2}$. Following that the selected concentration of the ethanolic extract or standard was added and cell viability was measure at $24 \mathrm{hr}$ intervals for maximum of $72 \mathrm{hr}$ using neutral red uptake assay as previously described.

\section{Statistical analysis}

All data are expressed as the mean \pm standard deviation (SD). The differences were considered to be statistically significant at $\mathrm{P}<0.05$. Statistical analyses were performed using Primer of Biostatistics program V5 for analysis of the unpaired Student's t-test and one-way analysis of variation (ANOVA).

\section{Results}

Preliminary phytochemical screening of barberry's roots revealed the presence of alkaloids, flavonoids, saponin, phenolic contents, terpenoids and cardiac glycosides. However, steroid and phobatannins were not detected. The percentage of alkaloids, flavonoids, saponin and total phenolic content were 4, 1.9, $0.35 \mathrm{~g} / 100 \mathrm{gm}$ plant tissue and $100 \mathrm{mg} / \mathrm{ml}$ of ethanolic extract, respectively (Table 3). Table 3 and Figure 1 showed that $1 \mathrm{mg}$ of berberis ethanolic extract contains $0.6 \mathrm{mg}$ berberine active compound.

Figure 2 showed that Berberis vulgaris and berberine chloride different concentrations exerted the same AChE inhibitory ability in percentage (\%) at $p<0.05$, this inhibitory effect was increased as the concentration of Berberis vulgaris and berberine chloride increased.

Both Berberis vulgaris and berberine chloride had $\alpha$ glucosidase inhibitory effect but the effect of Berberis crude extract was more potent than that of berberine chloride as shown in Figure 3. Furthermore, this inhibitory effect was directly proportional with that ingredient concentration at $p<0.05$.

Table 3 Quantitative phytochemical screening of barberry roots and Berberine concentration in Berberis vulgaris crude extract

\begin{tabular}{lc}
\hline Extract & Berberice concentration $(\mathrm{mg} / \mathbf{m g}$ extract) \\
\hline Ethanolic extract & 0.62 \\
\hline
\end{tabular}

The antioxidants effect of Berberis vulgaris crude extract and berberine chloride were tabulated in Table 4. Our results showed that both crude extract and active ingredient had powerful antioxidants properties as they inhibited the production of TBARS, NO and the oxidation of DPPH that associated with GPx and SOD hyperactivation. These biochemical properties were exerted in a concentration dependent manner where TBARS production decreased from $9 \pm 0.3 \mathrm{nmol} / \mathrm{g}$ to $4 \pm 1.1 \mathrm{nmol} / \mathrm{g}$ as the concentration of berberis crude extract increased from $0.2 \mathrm{mg} / \mathrm{ml}$ to $1 \mathrm{mg} / \mathrm{ml}$. The same pattern and the same inhibitory effect were shown with berberine chloride different concentrations. Both berberis extract and berberine chloride different concentrations ranged from $0.2-1 \mathrm{mg} / \mathrm{ml}$ lowered $\mathrm{NO}$ level in range from 16 to $25 \%$, respectively, at $p<0.05$. Furthermore, the same tested concentrations of $B$. vulgaris or berberine chloride inhibited the DPPH oxidation in range from 13 to $46 \%$ than control level at $p<0.05$. On the other hand, the GPx and SOD activities increased in the range of $10-70 \%$ and $55-270 \%$, respectively, when the concentration of Berberis vulgaris or berberine chloride increased from $0.2 \mathrm{mg} / \mathrm{ml}$ to $1 \mathrm{mg} / \mathrm{ml}$ as comparing with control levels.

The cytotoxicity study that was done on PBMC for both of $b$. vulgaris extract and berberine chloride, the main alkaloid constituent, showed that both of them had not any mentioned cellular toxicity while they had a significant proliferatory effect. As, different concentrations $(20,40,60,80$ and $100 \mu \mathrm{g} / \mathrm{ml})$ of both berberine chloride and barberry ethanolic extract showed to have inhibitory effect on normal blood cells (PBMC) growth rate maintenance, in contrary they slightly stimulated the proliferation of PBMC (Figure 4) especially after incubation for 72 hrs. At the same time as indicated in Figure 5, concentrations starting from $1 \mu \mathrm{g} / \mathrm{ml}$ up to $100 \mu \mathrm{g} / \mathrm{ml}$ of both berberine chloride and barberry ethanolic extract showed to have inhibitory effect on the growth of breast, liver and colon cancer cell lines (MCF7, HepG2 and CACO-2, respectively) at different incubation times starting from 24 hrs up to $72 \mathrm{hrs}$ and the inhibitory effect increased with time in a dose dependant manner. It was interest to notice that with time the inhibitory dose of both berberine chloride and barberry ethanolic extract increased with time in case of normal cells (PBMC) and decreased dramatically with time in case of cancer cells (Table 5).

\section{Discussion}

The phytochemical constituents of B. vulgaris act in synergism to increase barberry's bioactivity such as antioxidant, antimicrobial, anticholinergic, anti-diabetic, etc. [41]. In our previously published work, we mentioned that $B$. vulgaris ethanolic extract has a competitive 


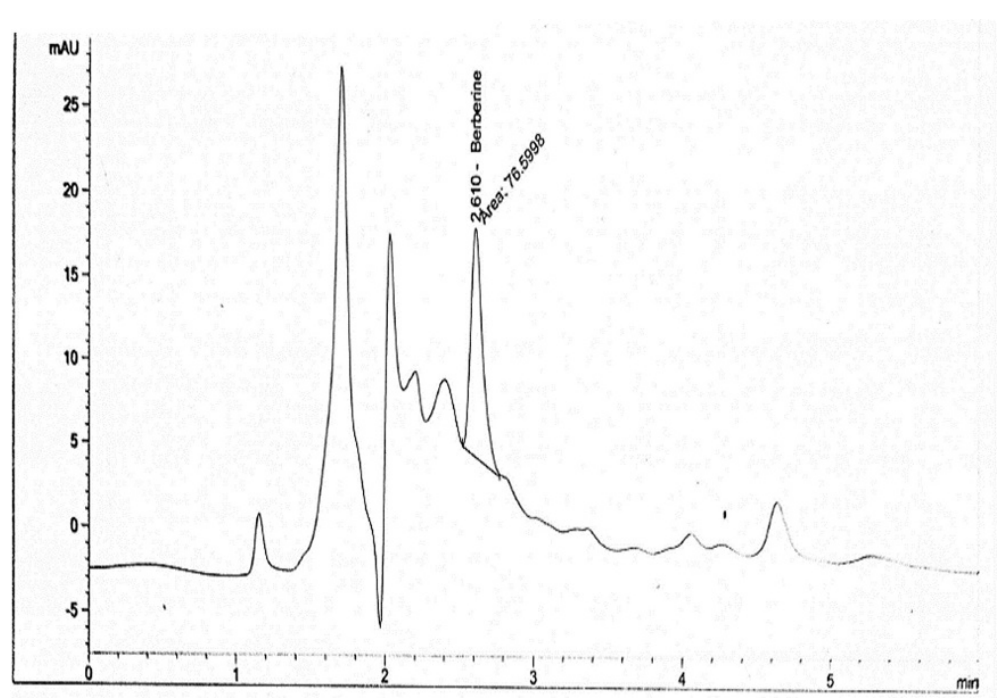

Figure 1 Berberis vulgaris ethanolic extract HPLC chart.

AChE inhibitory ability suggesting its use to alleviate over activity of AChE in dementia patients [42]. In agreement with this finding, our data showed the same inhibitory effect toward AChE enzyme. This inhibitory effect may be returned to the presence of berberine in ethanolic crude extract where it represented $60 \%$ of its ingredients. Berberine binds AChE active site as it is acts as competitive inhibitor that leads to enzyme conformational change and increases entropy value. AChE is mainly present in the central nervous system and its principle role is to catalyze the hydrolysis of the neurotransmitter acetylcholine (ACh) to choline. This process can return an activated cholinergic neuron back to its resting state. The pathogenesis of $\mathrm{AD}$ is linked to a

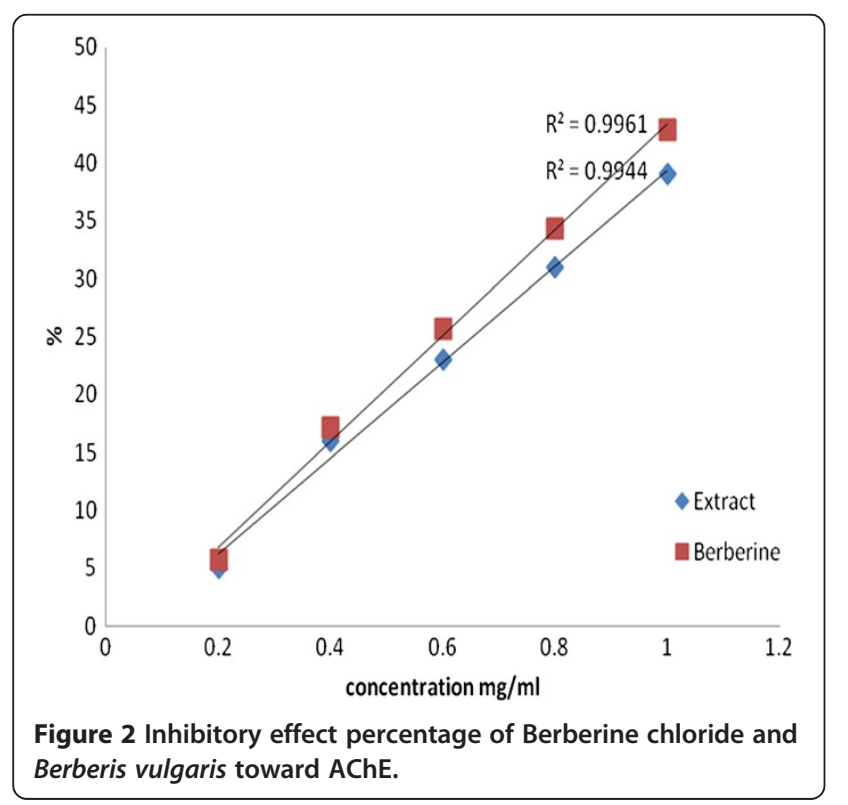

deficiency in the brain ACh [32]. Thus, AChE is an important pathogenic factor of $\mathrm{AD}$ and most pharmacological studies for screening agent to combat $\mathrm{AD}$ has been focused on AChE inhibitors to alleviate cholinergic deficit and improve neurotransmission [43].

$B$. vulgaris inhibited $\alpha$-glucosidase enzyme activity provides an effective way for diabetes treatment. The inhibition of $\alpha$-glucosidase activity is one of therapeutic approaches for reducing postprandial hyperglycemia. $\alpha$ Glucosidase inhibitor is effective in delaying absorption of carbohydrates and suppressing postprandial hyperglycemia which contribute to the decrease in hemoglobin A1C (HbA1c). The decreasing of HbA1c could reduce the incidence of chronic vascular complication in diabetic patients [44].

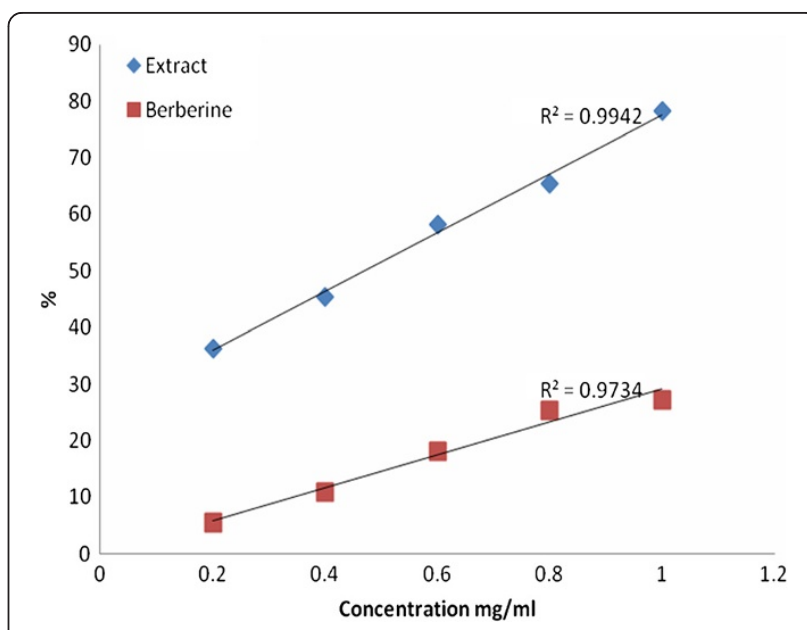

Figure 3 Inhibitory effect percentage of Berberine chloride and berberis vulgaris toward glucosidase. 
Table 4 Effect of berberine chloride and berberis on cellular prooxidants/antioxidants status

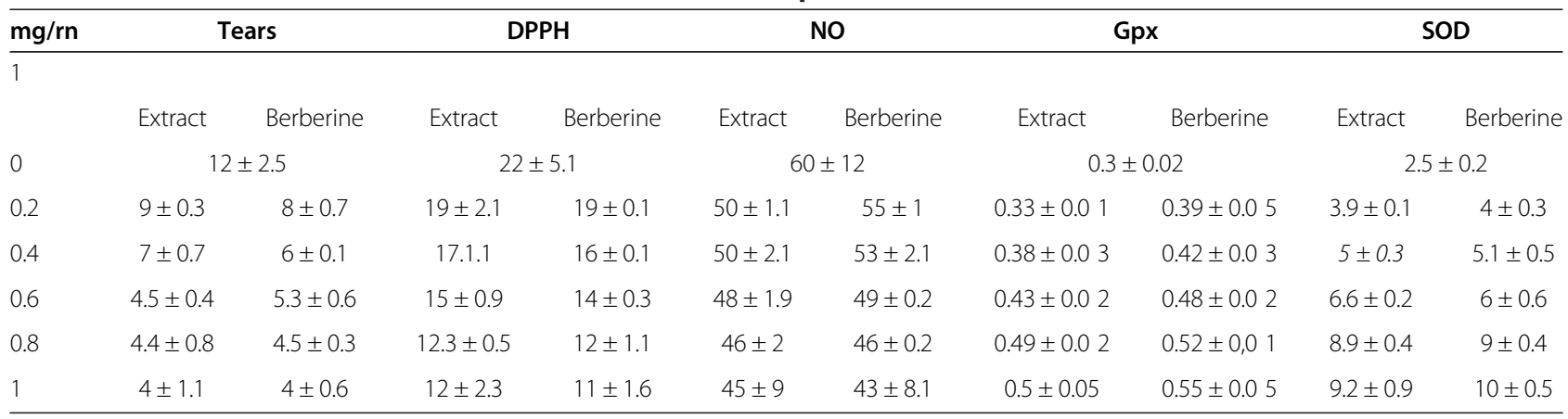

Both of TBARS and DPPH assays besides SOD and GPx activities give a complete picture about the total antioxidants capacity of the $B$. vulgaris ethanolic extracts. It is important to determine the relative antioxidant capacity of the extract since free radicals and oxidants in the body commonly cause damage to aqueous-based cellular structures and organelles as well as lead to peroxidation of lipids [45]. Berberis vulgaris ethanolic extract was a potent inhibitor for hepatocytes' lipid peroxidation induced by $\mathrm{Fe}^{2+}$ and $\mathrm{H}_{2} \mathrm{O}_{2}$. This finding was proved previously on acidic and methanolic barberry extracts [1], where berberine and barberry crude extract showed a significant reductive ability and radicals scavenging effects, especially on hydroxyl and DPPH radicals. Also, they have the ability to increase SOD and GPx activities. It is reported that the most polar solvent dissolving several compounds of different polarities such as acids, sugars or glycosides which may be contributed to the total phenolic content of the extract and represented the highly antioxidant properties. Depending on this we speculated that acetic acid extract preparations exhibited appreciable antioxidantive activity against the generation of cellular oxidized lipid particles [1].

Nitric oxide is an essential bioregulatory molecule required for several physiological processes like neural signal transmission, immune response, control vasodilatation and control of blood pressure. However, the elevation of the NO results in several pathological conditions, including cancer [46]. The plant/plant products may have the property to counteract the effect of NO formation and in turn may be of considerable interest in preventing the ill effects of excessive NO generation in vivo [46] B. vulgaris extract reduced the generation of NO in vitro in a concentration dependent manner. The implications of these findings may be very important for human health, since this herb has been used in several countries from ancient times. Further, the high scavenging activity may also help to arrest the chain of reactions initiated by excess generation of $\mathrm{NO}$, that are detrimental to the human health as excess NO is known to damage the immune system.

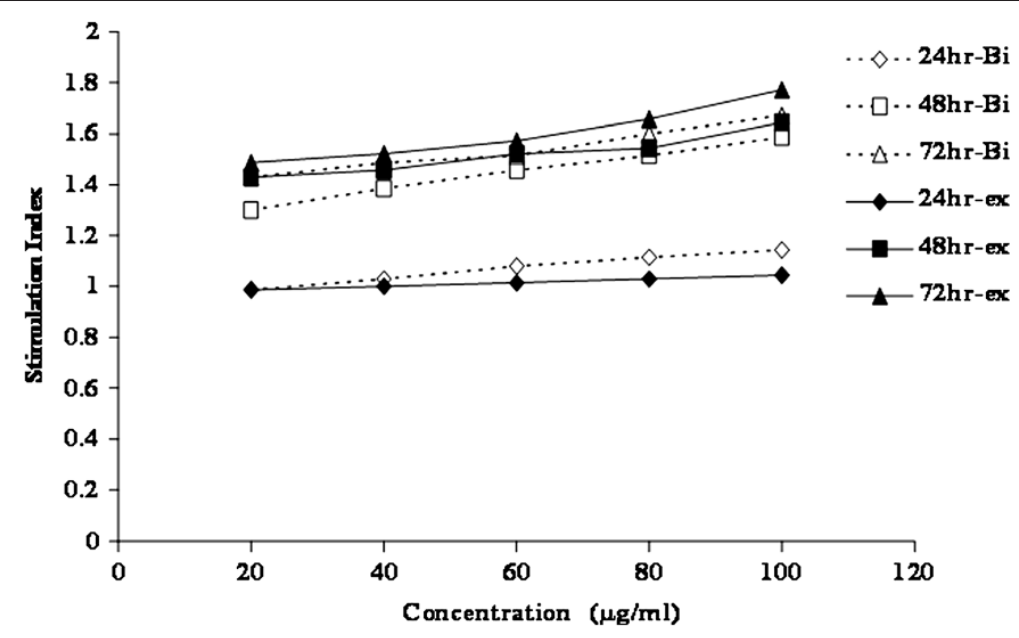

Figure 4 Effect of different concentrations of Berberine chloride (Bi) and Berberis vulgaris extract (ex) on proliferation of normal peripheral blood mono nuclear cells (PBMC) at 24, 48 and $72 \mathrm{hrs}$. Data were represented as stimulation index (SI). 


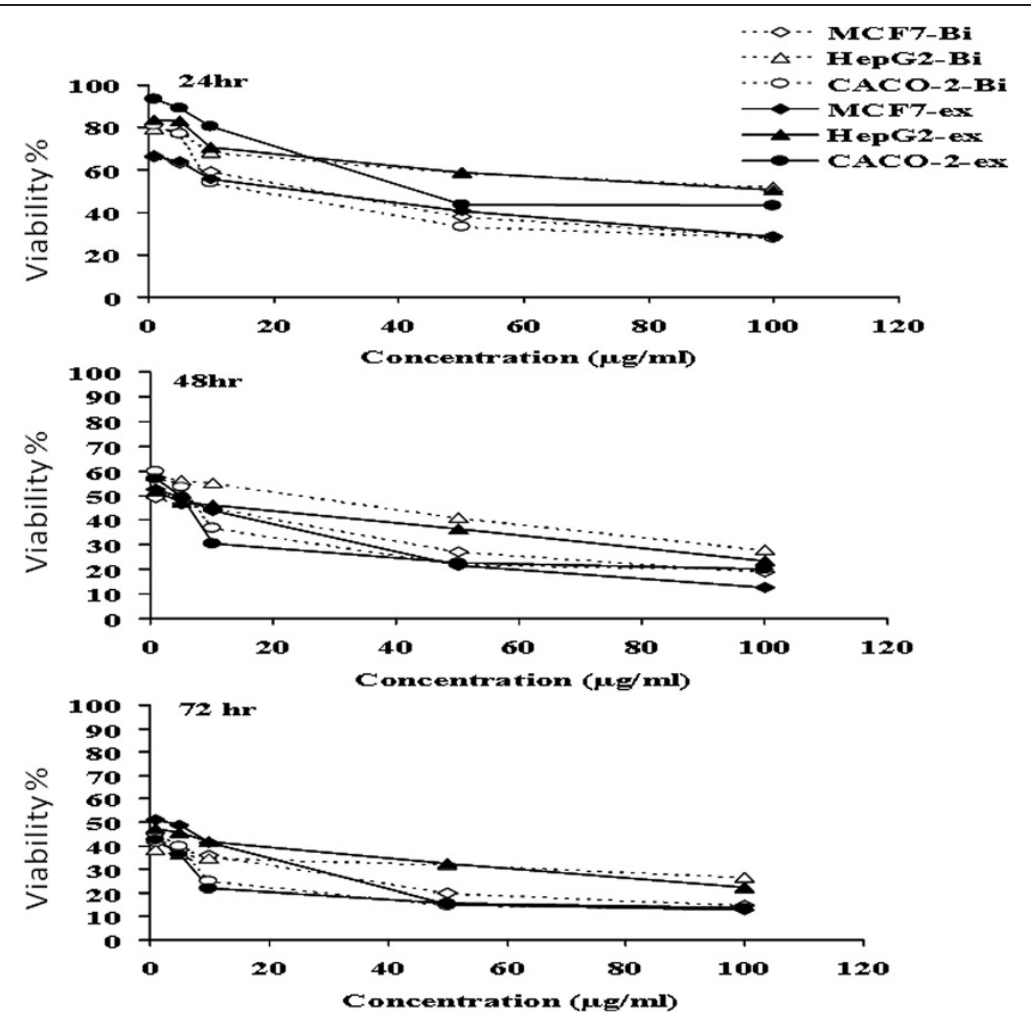

Figure 5 Effect of Berberine chloride (Bi) and Berberis vulgaris extract (ex) on viability of three human cancer cell lines. Different concentration of both Berberine chloride and berberis vulgaris were incubated with $10^{5}$ cells $/ \mathrm{ml}$ of breast cancer (MCF7), Liver Cancer (HepG2) and Colon cancer (CACO-2) cell lines (ATTC, see Methods) for 24, 48 and 72 hours, cell viability were evaluated by using neutral red cell stainig.

Chemotherapeutic drugs generally have low safety despite of their high efficacy. This might be due to toxicity and side effects that are usually associated with almost all types of chemotherapeutic medicine, besides the generated resistance to this group of therapeutic drugs which makes it more difficult to the patients. Between 1982 and 2002, more than half of the new anti-cancer chemical compounds were derived directly or indirectly from natural resources either microorganisms, plant or both $[47,48]$. Berberine as an isoquinoline alkaloid isolated from different types of plants is well recognized for its assorted pharmacological actions, for example

Table 5 Inhibition concentrations of both Berberine chloride and Berberis vulgaris that can inhibit the growth of $\mathbf{5 0 \%}$ of normal and cancer cells at different incubation time

\begin{tabular}{cccccccc}
\hline \multicolumn{7}{c}{$11250(\mathbf{m g} / \mathbf{m i})$} \\
\cline { 2 - 4 } \cline { 7 - 9 } & $\mathbf{2 4}$ & $\mathbf{4 8}$ & $\mathbf{7 2}$ & & $\mathbf{2 4}$ & $\mathbf{4 8}$ & $\mathbf{7 2}$ \\
\hline PBMC & 0.66649 & 5.568 & 883.994 & & 0.9019 & 6.051 & 2.546 \\
MCF7 & 0.01593 & 0.00443 & 0.00195 & & 0.01561 & 0.00454 & 0.00397 \\
Rep 02 & 0.06586 & 0.01149 & 0.00173 & 0.06805 & 0.00555 & 0.00408 \\
CAC 0-2 & 0.01764 & 0.0051 & 0.00183 & 0.04996 & 0.00384 & 0.00144 \\
\hline
\end{tabular}

berberine purified from Coptidis Rhizoma (Huanglian) is used in Chinese medicine for heat dissipation and detoxification [49], moreover, berberine purified from members of family

Berberidaceae is well known for its anti-inflammatory and immunosuppressive capacity beside other pharmacological activities [50-56]. Berberine is also recognized for its anti-cancer activity [56-64]. For assessment of anticancer effect of certain compounds, cytotoxicity on primary normal cell culture must be formed to calculate the safe dose. Several types of primary cells can be used; one of them is PBMC [65]. Furthermore, we based on neutral red assay for cytotoxicity study as it is reported that neutral red and the MTT assay being the most sensitive in detecting cytotoxic events compared to the LDH leakage and the protein assay [66]. Moreover, it is well known that berberine shifted the balance between Th2 and Th1, increased the production of IL 12 and altered the cytokines profile [67]. So, it mimics PHA response and in such cases PHA did not used to make cell stimulation because it could cause cell death due to cell overstimulation $[68,69]$.

In the present study, the anti-cancer activity of berberine chloride and total ethanolic extract from $B$. vulgaris was examined, in which this herb as member of the 
family Berberidaceae has not been identified before for its anti-cancer activity. At first, the dose for this in vitro testing was determined using healthy PBMC, and as indicated in Figure 3, for berberine chloride and $B$. vulgaris ethanolic extracts, both are slightly stimulate immune cells and the safety margin concentrations of both berberine chloride and B. vulgaris ethanolic extracts are significantly high $\left(\mathrm{IC}_{50}=0.66649,5.568\right.$ and $883.994 \mathrm{mg} / \mathrm{ml}$ after incubation at 24, 48 and 72 hours). Followed by examining the effect of $1,5,10,50$ and $100 \mu \mathrm{g} / \mathrm{ml}$ of both berberine chloride and $b$. vulgaris extracts on viability of breast, hepatic, colon and cervix cancer cell lines after incubation for 24, 48, and 72 hours. The cell viability of all cancer cell line used in this study was decreased significantly and in a dose dependent manner with both berberine chloride and berberis vulgaris ethanolic extracts (Figure 5 and Table 4). This data are in agreement with the published data about other members of family berberidaceae [56,58-60,64]. The mode of action of both berberine chloride and $b$. vulgaris ethanolic extracts were not determined during the course of the present study, but in another study performed in our laboratory (data not shown) that $\mathrm{p}_{53}$ expression was increased due to treatment with both berberine chloride and $b$. vulgaris ethanolic extracts. This might explain that $b$. vulgaris ethanolic extract can induce cancer cell death (apoptosis) through this mode of action. On the other hand, the antioxidant activity might play a major role in increasing efficiency of such extracts to kill cancer cells and protect normal cells.

\section{Conclusion}

This work demonstrates the potential of the bioactive ingredients of barberry on suppressing lipid peroxidation, suggesting a promising use in the treatment of hepatic oxidative stress, Alzheimer and idiopathic male factor infertility. Besides, berberis vulgaris ethanolic extract can induce cancer cell death that could return to its powerful antioxidant activity. Although the significant curative potential of $b$. vulgaris against many diseases, it didn't deposited in a publicly available herbarium yet. Thus, for further experimental investigations, protocol for ingredients' extraction mentioned in methods section is recommended to be followed. Furthermore, the plant has been registered in several herbarium and we use this as reference, also we purchased the root from USA market so how come we register it in our herbarium as it is not grown in Egypt but we will register the extract after we finish complete toxicological study $[31,70,71]$

\section{Competing interests}

The authors declare that they have no competing interests.

\section{Authors' contributions}

All authors designed the study, collected the data, performed the techniques employed in the study. GAD, AEA and EAM made the interpretation of statistical analyses and wrote the paper with input from all the authors who each approved the final version. All authors read and approved the final manuscript.

\section{Author details}

${ }^{1}$ Biochemistry Department, Faculty of Science, Alexandria University, P.O. Box: 21511, Alexandria, Egypt. ${ }^{2}$ Medical Biotechnology Department, Genetic Engineering \& Biotechnology Research Institute, City for Scientific Research \& Technology Applications, Alexandria, Egypt. ${ }^{3}$ Protein research Department, Genetic Engineering \& Biotechnology Research Institute, City for Scientific Research \& Technology Applications, Alexandria, Egypt.

Received: 2 March 2012 Accepted: 30 August 2013 Published: 5 September 2013

\section{References}

1. El-Sayed M, Ghareeb DA, Sarhan EM, Khalil AA: Therapeutic Bio-screening of the bioactive extracted ingredients of Berberis vulgaris, berberine. FPSB 2011, 5:63-68.

2. Harden GJ (Ed): Flora of New South Wales, Volume 1. Kensington: NSW University Press; 2000.

3. Grieve M: 1931. A Modern Herbal. London: Tiger Books International; 1994.

4. Arayne MS, Sultana N, Bahadur SS: The berberis story: Berberis vulgaris in therapeutics. Pakistan J Pharmacol Sci 2007, 20(1):83-92.

5. Zargari A: Medicinal Plants. Tehran: Tehran University Press; 1983, 1:68.

6. Chevallier A: The Encyclopedia of Medicinal Plants. St Leonards: Dorling Kindersley; 2001

7. Souri EAG, Dehmobed-Sharifabadi A, Nazifi A, Farsam H: Antioxidant activity of sixty plants from Iran. Iranian J Pharm Res 2004, 3:55-59.

8. Timothy CBN, Gregory S, Kelly ND: Berberine: therapeutic potential of an alkaloid found in several medicinal plants. Altern Med Rev 1997, 2:94-103.

9. Kunwar RM, Nepal BK, Kshhetri HB, Rai SK, Bussmann RW: Ethnomedicine in Himalaya: a case study from Dolpa, Humla, Jumla and Mustang districts of Nepal. J Ethnobiol Ethnomed 2006, 2:27.

10. Fatehi-Hassanabad Z, Jafarzadeh M, Tarhini A, Fatehi M: The antihypertensive and vasodilator effects of aqueous extract from Berberis vulgaris fruit on hypertensive rats. Phytother Res 2005, 19(3):222-225.

11. Ivanovska N, Philipov S: Study on the anti-inflammatory action of Berberis vulgaris root extract, alkaloid fractions and pure alkaloids. Int J Immunopharmacol 1996, 18(10):553-561.

12. Imanshahidi M, Hosseinzadeh $\mathrm{H}$ : Pharmacological and therapeutic effects of Berberis vulgaris and its active constituent, Berberine. Phytotherapy Research 2008. Published online at Wiley InterScience. Adv Physiol Educ. doi:10.1002/ptr.2399 (www.interscience.wiley.com).

13. Mills S, Bone K: Principals and Practice of Phytotherapy. Edinburgh: Churchill Livingstone; 2000.

14. Bone K: A Clinical Guide to Blending Liquid Herbs: herbal formulations for the individual patient. St Louis, Missouri: Churchill Livingstone; 2003.

15. Li SY, Ling LH, Teh BS, Seow WK, Thong YH: Anti-inflammatory and immuno-suppressive properties of the bis-benzylquinolones: in-vitro comparisons of tetrandrine and berbamine. Int J Immunopharmacol 1989, 11:395-441.

16. Khosrokhavar R, Ahmadiani ASF: Antihistaminic and Anticholinergic Activity of Methanolic Extract of Barberry Fruit (Berberis vulgaris) in the Guinea- Pig lleum. J Med Plants 2010, 9:99-105.

17. Akhter MH: SMaBN: Possible mechanism of antidiarrheal effect of berberine. Indian J Med Res 1979, 70:233-241.

18. Rabbani GHBT, Knight J, Sanyal SC, Alam K: Randomized controlled trial of berberine sulfate therapy for diarrhea due to enterotoxigenic Escherichia coli and Vibrio cholera. J Infect Dis 1987, 155:979-984.

19. Amin AH, Subbaiah TV, Abbasi KM: Berberine sulfate: antimidrobial activity, bioassay, and mode of action. Can J Microbiol 1969, 15:1067-1076

20. Leung AY, Foster S: Encyclopedia of Common Natural Ingredients Used in Food, Drugs and Cosmetics. New York: Wiley Publishers; 1996:66-67. 
21. Imanshahidi M, Hosseinzadeh $\mathrm{H}$ : Pharmacological and therapeutic effects of Berberis vulgaris and its active constituent, berberine. Phytother Res 2008, 22:999-1012.

22. Sabir M: Study of some pharmacological actions of berberine. Indian J Physiol Pharmacol 1971, 15:111-132.

23. Kuo C, Chi C, Liu T: The anti-inflammatory potential of berberine in-vitro and in-vivo. Cancer Lett 2004, 203:127-137.

24. Zhou H, Mineshita S: The effect of berberine chloride on experimental colitis in rats in vivo and in vitro. J Pharmacol Exp Ther 2000, 294(3):822-829.

25. KF L: Berberine. In Adverse Effects of Herbal Drugs. Edited by Pagm KK, Hansel R, Chandler RF. Berlin: Springer Verlag; 1994:97-98.

26. Shamsa F, Ahmadiani A, Khosrokhavar R: Antihistaminic and anticholinergic activity of berberry fruit (Berberis vulgaris) in the guinea-pig ileum. J Ethnopharmacol 1999, 64:161-166.

27. Tomosaka H, Salim AA, Keller WJ, Chai H, Kinghorn AD: Antioxidant and cytoprotective compounds from Berberis vulgaris (barberry). Phytothe Res 2008, 22:979-981.

28. Cohen-Boulakia F: In-vivo sequential study of skeletal muscle capillary permeability in diabetic rats. Metabolism 2000, 49:880-885

29. Meiers S: The anthocyanidins cyaniding and delphinidin are potent inhibitors of the epidermal growth factor receptor. J Agric Food Chem 2000, 49:958-962.

30. http://www.mohp.gov.eg/default.aspx\#, Egyptian Ministry of Health and Population, Arab Republic of Egypt, 9/5/2013, 11:30 PM.

31. http://www.dragonherbarium.com/bulk-herbs-spices/bulk-herbs-b/barberryroot-bark-cs-wc-berberis-vulgaris.

32. Qadir S, Han J, Ji H, Chung H, Ahn J, Lee H: Effect of different extraction protocols on anticancer and antioxidant activities of berberis koreana bark extracts. J Biosci Bioeng 2009, 107:331-339.

33. Ellman $G$, Andres $V$, Featherstone RA: New and rapid colorimetric determination of acetylcholinesterase activity. Biochem Pharmacol 1961, 7:88-95.

34. Han YN, Srinivasan VR: Purification and characterization of betaglucosidase of Alcaligenesfaecalis. J Bacteriol 1969, 100:1355-1363.

35. Wills ED: Mechanisms of lipid peroxide formation in animal tissues. Biochem J 1965, 99(3):667-676.

36. Choi DW, King YC, Leroy P, Siest G, Wellman M: Differential role of CYP2E1 binders and isoniazid on CYP2E1 protein modification in NADPHdependent microsomal oxidative reactions: FR scavenging ability of isoniazid. Free Radic Res 2002, 36:893-904

37. Green LC, Glogowski J: Analysis of nitrate, nitrite and nitrate in biological fluids. Anal Biochem 1982, 126:131-138.

38. Marklund S, Marklund G: Involvement of the superoxide anion radical in the auto oxidation of pyrogallol and a convenient assay for superoxide dismutase. Eur J Biochem 1974, 74:469-474.

39. Paglia $\mathrm{E}$, Valentine N: Studies on the quantitative and qualitative characterization of erythrocyte glutathione peroxidase. J Lab Clinic Med 1967, 70:158-169.

40. Repetto G, Zurita J: Neutral red uptake assay for the estimation of cell viability/cytotoxicity. Nat Protoc 2008, 3:1125-1131.

41. Wongbutdee J: physiological effects of berberine. Thai Pharm Health Sci J 2008, 4:78-83.

42. Ghareeb D, Newarry A, El-Rashidy F, Hussein H, Ali A: Efficacy of natural extracts of Ginkgo biloba and barberry and a synthetic derivative of genistein (ipriflavone), as acetylcholinesterase inhibitors, comparative study with Aricept ${ }^{\oplus}$ effect. J Biochem Biotechnol 2010, 1:15-20.

43. Muñoz-Torrero D: Acetylcholinesterase inhibitors as disease-modifying therapies for Alzheimer's disease. Curr Med Chem 2008, 15:2433-2455.

44. Yibchok-anun S, Jittaprasatsin W, Somtir D, Bunlunara W, Adisakwattana S: Insulin secreting and a-glucosidase inhibitory activity of Coscinium fenestratum and postprandial hyperglycemia in normal and diabetic rats. J Med Plants Res 2009, 3(9):646-651.

45. Bijvoet A, Pieper F, Vliet M, Boer H, Ploeg A, Verbeet M, Reuser A: Recombinant human acid a-glucosidase: high level production in mouse milk, biochemical characteristics, correction of enzyme deficiency in GSDII KO mice. Hum Mol Genet 1998, 7:1815-1824.

46. Frei B: Natural antioxidants in human health and disease. San Diego: Academic Press; 1994

47. Jagetia G, Baliga M, Babu K: The Evaluation of Nitric Oxide Scavenging Activity of Certain Herbal Formulations in vitro: A Preliminary Study. Phytother Res 2004, 18:561-565.
48. Tan W, Huang M, Li Y, Chen M, Wu G, Gong J, Zhong Z, Xu Z, Dang Y, Guo J, Chen $X$, Wang $Y$ : Anti-cancer natural products isolated from chinese medicinal herbs. Chin Med 2011, 6:27-43.

49. Newman DJ, Snader KM: Natural products as sources of new drugs over the period 1981-2002. J Nat Prod 2003, 66:1022-1037.

50. Ong ES, Woo SO, Yong YL: Pressurized liquid extraction of berberine and aristolochic acids in medicinal plants. J Chromatogr A 2000, 904:57-64.

51. Yoo KY, Hwang IK, Kim JD, Kang IJ, Park J, Yi J, Kim JK, Bae YS, Won MH: Antiinflammatory effect of the ethanol extract of Berberis koreana in a gerbil model of cerebral ischemia/reperfusion. Phytother Res 2008, 22(11):1527-32.

52. Yoo KY, Hwang IK, Lim BO, Kang TC, Kim DW, Kim SM, Lee HY, Kim JD, Won MH: Berberry extract reduces neuronal damage and N-Methyl-D-aspartate receptor 1 immunoreactivity in the gerbil hippocampus after transient forebrain ischemia. Biol Pharm Bull 2006, 29(4):623-628.

53. Cho BJ, Im EK, Kwon JH, Lee KH, Shin HJ, Oh J, Kang SM, Chung JH, Jang Y: Berberine inhibits the production of lysophosphatidylcholine-induced reactive oxygen species and the ERK1/2 pathway in vascular smooth muscle cells. Mol Cells 2005, 20(3):429-434.

54. Musumeci R, Speciale A, Costanzo R, Annino A, Ragusa S, Rapisarda A, Pappalardo MS, lauk L: Berberis aetnensis C. Presl. extracts: antimicrobial properties and interaction with ciprofloxacin. Int J Antimicrob Agents 2003, 22(1):48-53.

55. Chung JG, Chen GW, Hung CF, Lee JH, Ho CC, Ho HC, Chang HL, Lin WC, Lin JG: Effects of berberine on arylamine $\mathrm{N}$-acetyltransferase activity and 2 aminofluorene-DNA adduct formation in human leukemia cells. Am J Chin Med 2000, 28(2):227-238.

56. Ivanovska N, Philipov S, Hristova M: Influence of berberine on T-cell mediated immunity. Immunopharmacol Immunotoxicol 1999, 21(4):771-86.

57. Fukuda K, Hibiya Y, Mutoh M, Koshiji M, Akao S, Fujiwara H: Inhibition by berberine of cyclooxygenase-2 transcriptional activity in human colon cancer cells. J Ethnopharmacol 1999, 66(2):227-33.

58. Mahata S, Bharti AC, Shukla S, Tyagi A, Husain SA, Das BC: Berberine modulates AP-1 activity to suppress HPV transcription and downstream signaling to induce growth arrest and apoptosis in cervical cancer cells. Mol Cancer 2011, 10:39.

59. Kim JB, Yu JH, Ko E, Lee KW, Song AK, Park SY, Shin I, Han W, Noh DY: The alkaloid Berberine inhibits the growth of Anoikis-resistant MCF-7 and MDAMB-231 breast cancer cell lines by inducing cell cycle arrest. Phytomedicine 2010, 17(6):436-740.

60. Wang GY, Lv QH, Dong Q, Xu RZ, Dong QH: Berbamine induces Fas-mediated apoptosis in human hepatocellular carcinoma HepG2 cells and inhibits its tumor growth in nude mice. J Asian Nat Prod Res 2009, 11(3):219-28.

61. Ho YT, Yang JS, Lu CC, Chiang JH, Li TC, Lin JJ, Lai KC, Liao CL, Lin JG, Chung JG: Berberine inhibits human tongue squamous carcinoma cancer tumor growth in a murine xenograft model. Phytomedicine 2009, 16 (9):887-890.

62. Hsieh YS, Kuo WH, Lin TW, Chang HR, Lin TH, Chen PN, Chu SC: Protective effects of berberine against low-density lipoprotein (LDL) oxidation and oxidized LDL-induced cytotoxicity on endothelial cells. J Agric Food Chem 2007, 55(25):10437-10445

63. Lin SS, Chung JG, Lin JP, Chuang JY, Chang WC, Wu JY, Tyan YS: Berberine inhibits arylamine $\mathrm{N}$-acetyltransferase activity and gene expression in mouse leukemia L 1210 cells. Phytomedicine 2005, 12(5):351-358

64. Fukuda K, Hibiya Y, Mutoh M, Koshiji M, Akao S, Fujiwara H: Inhibition of activator protein 1 activity by berberine in human hepatoma cells. Planta Med 1999, 65(4):381-387.

65. Jenny M, Wondrak A, Zvetkova E, Tram N, Phiz P5, Schennach H, Culig Z, Ueberall F, Fuchs D: Crinum Latifolium Leave Extracts Suppress Immune Activation Cascades in Peripheral Blood Mononuclear Cells and Proliferation of Prostate Tumor Cells. Sci Pharm 2011, 79:323-335.

66. Fotakis $\mathrm{G}$, Timbrell A: In vitro cytotoxicity assays: comparison of $\mathrm{LDH}_{\text {, }}$ neutral red, MTT and protein assay in hepatoma cell lines following exposure to cadmium chloride. Toxicol Lett 2006, 160(2):171-177.

67. Kim T, Kang B, Cho D, Kim S: Induction of interleukin-12 production in mouse macrophages by berberine, a benzodioxoloquinolizine alkaloid, deviates CD4 + T cells from a Th2 to a Th1 response. Immunology 2003, 109(3):407-414.

68. Kenny T, Keen C, Schmitz H, Gershwin M: Immune Effects of Cocoa Procyanidin Oligomers on Peripheral Blood Mononuclear Cells. Exp Biol Med 2007, 232:293-300. 
69. Kashyap R, Husain A, Morey S, Panchbhai M, Deshpande P, Purohit H, Taori G, Daginawala H: Assessment of immune response to repeat stimulation with BCG vaccine using in vitro PBMC model. J Immune Based Ther Vaccin 2010, 8:3.

70. http://plants.usda.gov/core/profile?symbol=bevu.

71. http://clarysageherbarium.com/herbs-etc//bulk-herbs/b.

doi:10.1186/1472-6882-13-218

Cite this article as: Abd El-Wahab et al.: In vitro biological assessment of berberis vulgaris and its active constituent, berberine: antioxidants, antiacetylcholinesterase, anti-diabetic and anticancer effects. BMC

Complementary and Alternative Medicine 2013 13:218.

\section{Submit your next manuscript to BioMed Central and take full advantage of:}

- Convenient online submission

- Thorough peer review

- No space constraints or color figure charges

- Immediate publication on acceptance

- Inclusion in PubMed, CAS, Scopus and Google Scholar

- Research which is freely available for redistribution 